\title{
GMR
}

\section{Genetic relationships in a germplasm collection of Camellia japonica and Camellia oleifera using SSR analysis}

\author{
Y. Zhao', C.J. Ruan' ${ }^{1}$, G.J. Ding ${ }^{1}$ and S. Mopper ${ }^{2}$ \\ ${ }^{1}$ Institute of Plant Resources, Dalian Nationalities University, Dalian, \\ Liaoning, China \\ ${ }^{2}$ Ecology Center, Biology Department, University of Louisiana, Lafayette, \\ LA, USA \\ Corresponding author: C.J. Ruan \\ E-mail: ruan@dlnu.edu.cn \\ Genet. Mol. Res. 16 (1): gmr16019526 \\ Received November 7, 2016 \\ Accepted January 24, 2017 \\ Published February 16, 2017 \\ DOI http://dx.doi.org/10.4238/gmr16019526
}

Copyright $(2017$ The Authors. This is an open-access article distributed under the terms of the Creative Commons Attribution ShareAlike (CC BY-SA) 4.0 License.

\begin{abstract}
Camellia japonica produces different color and bigger flowers, widely being used for gardening green in southern China. However, cultivars were introduced from different regions, but their origin and pedigree information is either not available poorly documented, causing problems in authentication. Many low-yield trees in Camellia oleifera forests have been used as stocks for grafting $C$. japonica. However, the survival rate of grafts between these two species is related to genetic relationship between stock of $C$. oleifera and scion of $C$. japonica. We used simple sequence repeat (SSR) markers to genotype $41 C$. japonica cultivars from different regions, as well as nine genotypes of $C$. oleifera in China. Twenty-one SSR markers generated 438 alleles, with an average of 20.85 alleles per locus. All alleles were used to generate Dice coefficients between two genotypes of all genotypes of these two species. Cluster analysis based on SSR data clustered genotypes showed clustering of genotypes into groups
\end{abstract}

Genetics and Molecular Research 16 (1): gmr16019526 
that agreed well with their taxonomic classification and geographic origin. Cultivar 'Damaonao' was a large tree with flowers of composite color, and showed the most genetic distance from other $C$. japonica cultivars and C. oleifera genotypes in the cluster analysis. The cultivars of $C$. japonica are distinct from genotypes of $C$. oleifera. The results for cultivars of $C$. japonica also revealed the presence of different cultivars with the same name, and identical cultivars but with a different name. SSR profiles can improve $C$. japonica germplasm management, and provide potential determine correlations between genetic relationship and graft compatibility among scions of $C$. japonica and genotypes of $C$. oleifera.

Key words: Camellia japonica; SSR marker; Genotypes; Genetic relationship; Germplasm management

\section{INTRODUCTION}

The genus Camellia (Theaceae) includes about 250 species of evergreen shrubs and trees, many of which are notable for their economic and ornamental value. Notably Camellia sinensis produces tea, Camellia oleifera produces edible oils, and Camellia japonica produces ornamental flowers. C. japonica, an insect- and bird-pollinated, broad-leaved evergreen tree, is widely distributed in China, Japan and the southern Korean peninsula (Chung et al., 2003). Native species are known for their large, conspicuous flowers (1-12 cm in diameter) with five to nine petals. Flower colors vary from white to pink to red, while yellow flowers are found only in South China and Vietnam. Our observation showed that $C$. japonica reaches sexual maturity and produces flowers after a juvenile period of about 5-10 years. At present, the $C$. japonica is widely being used for gardening green, such as family courtyard, surrounding house, public garden, and urban road.

To improve flower color and size, over 100 cultivars of $C$. japonica were successfully selected and bred in East Asia using conventional breeding programs such as crossing and pedigree selection. In China, over 50 cultivars were selected or introduced from different regions, but their origin and pedigree information is either not available or poorly documented, causing problems in authentication. For example, someone could sell one renamed cultivar in the market, but in fact this cultivar could be introduced from other breeder and then was renamed. In addition, recently, the plants of $C$. japonica with tall tree crown are becoming more and more popular in the market of southern China. However, the plant growth of $C$. japonica is very slow; it is about 10-20 years until one plant with tall tree crown.

The tea oils extracted from the seeds of $C$. oleifera contain bioactive compounds with powerful nutritional and medicinal value (Estevinho et al., 2012; Jin, 2012; Salinero et al., 2012). This seed oils contain large concentrations of oleic acid (Lee et al., 2007) and other bioactive compounds such as vitamin E and squalene (Estevinho et al., 2012). Oleic acid oils lower cholesterol and triglycerides and help prevent cardiovascular diseases (Tholstrup et al., 2004). The triterpenoid saponin improves immune function, enhances antibacterial and antiviral activities, and has antimutation and antioxidation properties (Zhan, 1999). In China, C. oleifera has been being widely cultivated for oil and ecoenvironmental restoration since 1960, reaching a production area of 3.3 million ha in 2015 . About $73 \%$ of the forests were planted in the 1960's and 1970's using heterogeneous

Genetics and Molecular Research 16 (1): gmr16019526 
seedling mixes. Many of these trees have a fresh fruit yield of $0-1.5 \mathrm{~kg} / \mathrm{year}$ and were considered "low-yield trees". These low-yield trees have strong resistance to drought and poor soil and growing vigor, with $100+$ year lifespans; which have been used as stocks for grafting $C$. japonica by the method of high-grafting and change-crown (Zhang et al., 2015). Then, the tall tree crown could be formed 2-3 years after grafts. The survival rate of grafts between these two species is decided by the genetic relationship between stocks of C. oleifera and scions of C. japonica; however, there is no report on genetic relationship between these two species.

Morphological traits are important indices for taxonomic classification of C. japonica cultivars, but they cannot adequately reveal genetic differences because phenotypic traits are highly influenced by environmental conditions (Fufa et al., 2005; Li et al., 2009). In contrast, molecular markers are not influenced by the environment, and can be used to distinguish germplasm (Ali et al., 2008). Several kinds of molecular markers, such as random amplified polymorphic DNA, inter-simple sequence repeat (ISSR), amplified fragment length polymorphism, and sequence-related amplified polymorphism, have been widely used to identify genetic relationship and diversity of germplasm, to construct linkage map and fingerprinting, and to reveal phylogenetic evolution (Wang et al., 2011; Zaloglu et al., 2015; Ding et al., 2016). However, these dominant markers have limited application in marker-assisted breeding and integrating genetic linkage maps, especially in heterozygous out-breeding perennial species in the genera such as Camellia (Zaloglu et al., 2015).

Simple sequence repeat (SSR) or microsatellite markers are tandemly repeated DNA sequences that occur randomly and frequently in eukaryotic genomes. Compared to dominant markers, SSR markers are co-dominant, highly reproducible, multi-allelic, and widely used in plant sciences (Hajmansoor et al., 2013) for germplasm characterization (Varshney et al., 2005; Peng et al., 2015; Queiroz et al., 2015), identification of genetic diversity (Gurcan et al., 2015; Jo et al., 2015; Mahjbi et al., 2016; Mornkham et al., 2016; Neiva et al., 2016), germplasm fingerprinting (Zhang et al., 2015), and integration of genetic linkage maps (Lai et al., 2013). For C. sinensis, SSR markers have been widely used to identify germplasm genetic diversity (Taniguchi et al., 2014), construction of linkage maps (Tan et al., 2013) and DNA-fingerprinting (Ujihara et al., 2009; Ma et al., 2010). Based on the C. sinensis sequences in the NCBI (National Center for Biotechnology Information), three SSR markers for C. japonica were developed (Ueno and Tsumura, 2009). Recently, developed 15 genic-SSR markers for $C$. oleifera were developed based on transcriptome sequencing. These successfully amplified PCR products with expected size and polymorphisms in 15 cultivars of C. japonica (Jia et al., 2014). Fifty-two SSRs developed from transcriptome sequencing revealed polymorphism in 20 cultivars of $C$. oleifera, with number of alleles per locus ranging from 2 to 15 and expected heterozygosity values from 0.269 to 0.888 . Cross-species transferability rates in Camellia chekangoleosa and C. japonica were 90.4 and $78.8 \%$, respectively (Jia et al., 2015).

In the present study, 21 genic-SSR markers were developed using RNA-Seq. These markers were used to authenticate $41 C$. japonica cultivars and nine genotypes of $C$. oleifera, and to estimate their genetic relationships. The application of SSRs profiles in pre-breeding, breeding, and identification of $C$. japonica germplasm collections is discussed, as well as a potential strategy for improving grafting survival rates based on genetic coefficients between stocks of $C$. oleifera and scions of $C$. japonica.

Genetics and Molecular Research 16 (1): gmr16019526 


\section{MATERIAL AND METHODS}

\section{Plant material}

Fifty genotypes were used in this study: 41 genotypes of $C$. japonica cultivars (11 from Yunnan Province and 30 from Zhejiang Province). Additional nine genotypes belonged to C. oleifera ('Changlin27' from Jiangxi Province, 'Xiang210' and 'Xianglin5' from Hunan Province, and 'NP1', 'NP2', 'NP3', 'NP56', 'NP57', and 'NP58' from Guizhou Province). The cultivars of $C$. japonica were selected because they have been planted widely in southern China, grow well and have many desirable agronomic traits (e.g., different color and size of flowers; Figure 1 and Table 1), 11 of them were selected and bred in Yunnan province and the remaining 30 were selected and bred in Zhejiang province. The genotypes of $C$. oleifera have been widely planted in southern China, which produced many low-yield trees with strong resistance to drought and poor soil and growing vigor. These trees could provide full of stocks for grafts of scions of $C$. japonica.

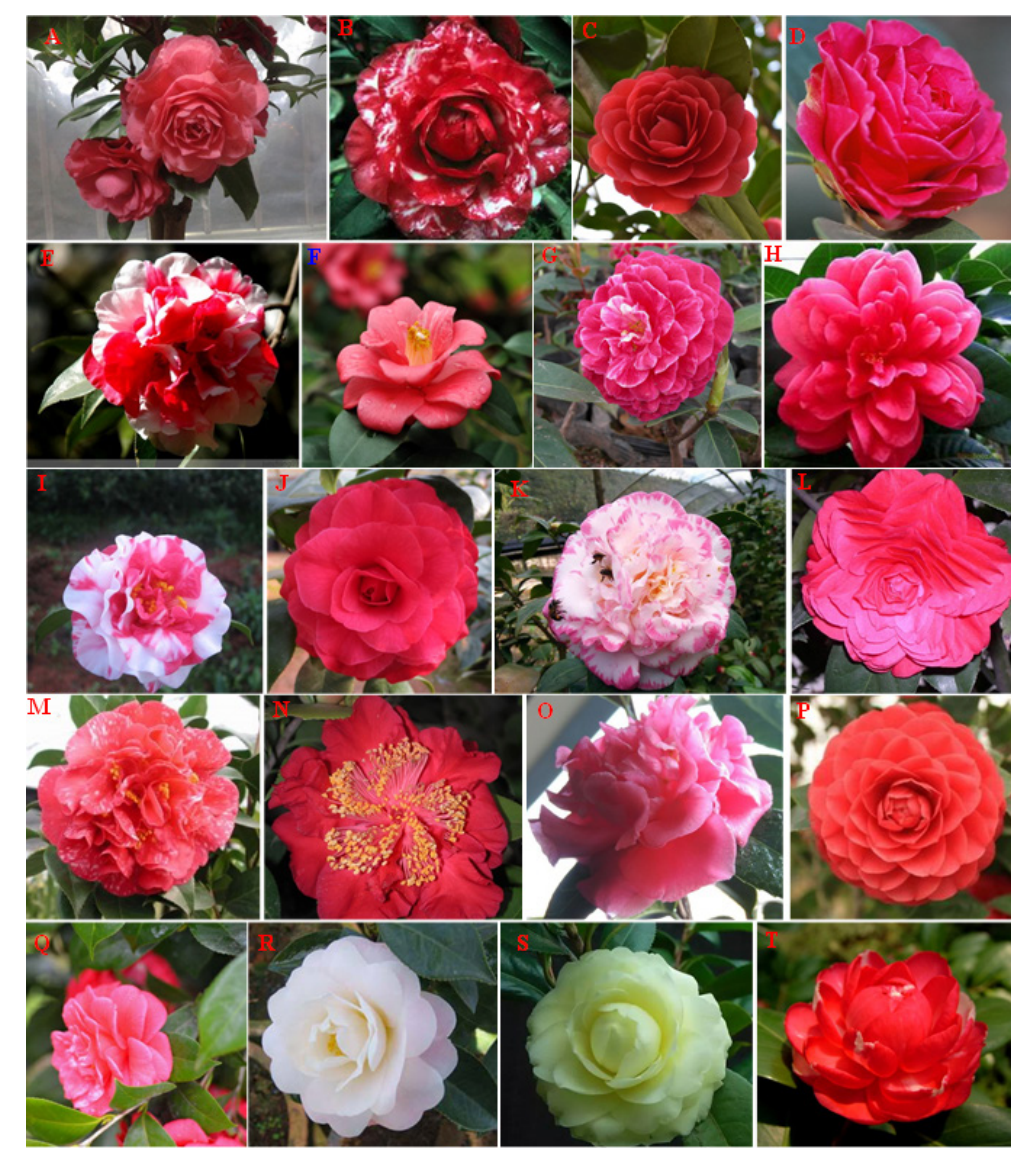

Figure 1. Several cultivars of Camellia japonica: A. Beila; B. Chalisidun; C. Chidan; D. Dalicha; E. Damanao; F. Dasongzi; G. Dandinghe; H. Hentiangao; I. Hualuzhen; J. Huaxianzi; K. Kuancaidai; L. Liujiaodahong; M. Moshucheng; N. Nantianwushi; O. Qiumudan; P. Shizitou; Q. Tongzimian; R. Xinsonghua; S. Zhenghuangqi; T. Zihudie. 


\section{Table 1. Genotypes of Camellia japonica and Camellia oleifera used in this study.}

\begin{tabular}{|c|c|c|c|}
\hline Species & Origin & Genotypes (No.) & Traits \\
\hline \multirow[t]{41}{*}{ Camellia japonica } & \multirow[t]{11}{*}{ Yunnan Province } & Jinxinfurong (1) & $\begin{array}{l}\text { Semidouble and lotus type, red, base connate and cylindrical flowers, with 6-7 cm diameter and 5-7 } \\
\text { petals }\end{array}$ \\
\hline & & Dalidiechi (2) & $\begin{array}{l}\text { Semidouble and butterfly wing type, red flowers, normal male and female, big and flat outer petals, } \\
\text { shaped inner petal }\end{array}$ \\
\hline & & Xuejiao (3) & $\begin{array}{l}\text { Semidouble and white flowers with red outer petals, elliptic to oblong leaves, flower diameter 12- } \\
15 \mathrm{~cm} \text {, about } 26 \text { petals, florescence: Jan.-Feb. }\end{array}$ \\
\hline & & Dandinghe (4) & $\begin{array}{l}\text { Semidouble, red, slightly cupped flowers, inner petals with pinkish white stripe, silver white haired } \\
\text { rest on other petals }\end{array}$ \\
\hline & & Songzikui (5) & $\begin{array}{l}\text { Rose-petal and red flowers, few stamens, pistil development or abortion, flower diameter 6-7 cm, } \\
\text { florescence: early Feb. - early March }\end{array}$ \\
\hline & & Fengshancha (6) & $\begin{array}{l}\text { Rose-petal and red flowers, stamens numerous, flower of multicomponent, pistil degradation; flower } \\
\text { diameter } 10-13 \mathrm{~cm} \text {, florescence: Feb.- March }\end{array}$ \\
\hline & & Dalicha (7) & $\begin{array}{l}\text { Doulbe, peony and purple red flowers, } 12-22 \mathrm{~cm} \text { flower diameter, over } 30 \text { petals, florescence: Jan.- } \\
\text { March }\end{array}$ \\
\hline & & Zaodudan (8) & Peony and purple red flowers, flower diameter $10-12 \mathrm{~cm}$ \\
\hline & & Shizitou (9) & $\begin{array}{l}\text { Peony and red flowers, flat outer and twist inner petals, stamens numerous, multicomponent mixed } \\
\text { born petals pistil most tortuous, florescence: Jan.- March }\end{array}$ \\
\hline & & Dazipao (10) & $\begin{array}{l}\text { Peony and deep red flowers; imbricate, rarely in the round rolling slightly undulating irregular; } \\
\text { stamens numerous petal, pistil degeneration; flower diameter } 11 \text { - } 13 \text { centimeters, maximum to } 16 \\
\text { cm; florescence: Jan. - March }\end{array}$ \\
\hline & & Damanao (11) & $\begin{array}{l}\text { Double, peony and multi-color flowers, flat outer and twist inner petals, stamens numerous, } \\
\text { multicomponent mixed born petals pistil most tortuous, florescence: Jan.- March }\end{array}$ \\
\hline & \multirow[t]{30}{*}{ Zhejiang Province } & Dasongzi (12) & $\begin{array}{l}\text { Semidouble and dark red flowers, petals reflexed, central with a tube of stamens, } 8 \mathrm{~cm} \text { flower } \\
\text { diameter, florescence: late Feb. -March }\end{array}$ \\
\hline & & Wuyepiaoyun (13) & $\begin{array}{l}\text { Semidouble to peony type, black red flowers with white cloud shaped patches, petals valgus, with a } \\
\text { golden stamen }\end{array}$ \\
\hline & & Meibuer (14) & Semidouble and white with pink spots flowers \\
\hline & & Jiaomeiren (15) & $\begin{array}{l}\text { Semidouble to peony type or even completely double leaf type; pale pink flowers; giant flowers, } \\
\text { with an average diameter of } 13.5 \mathrm{~cm}, 5-8 \mathrm{~cm} \text { thick; opened in early flowering }\end{array}$ \\
\hline & & Xinsonghua (16) & $\begin{array}{l}\text { Semidouble and red flowers, petals 4-5 round center with fine petals and stamens, flowers resembling } \\
\text { pine nuts, pine nuts but large petals reflexed, the upper end of the recess; florescence: Feb. - March }\end{array}$ \\
\hline & & Nantianwushi (17) & Double or peony and rose red with white patches or clouds flower, middle or large flower \\
\hline & & Zhenghuangqi (18) & Semidouble or double type; yellow flower \\
\hline & & Tongzimian (19) & $\begin{array}{l}\text { Rose-petal and pink white flower, petals imbricate arrangement, 5-7 wheel, left a few pieces in } \\
\text { stamen, pistil became flat }\end{array}$ \\
\hline & & Manaol (20) & Rose-petal and pink red flower, $12-15 \mathrm{~cm}$ flower diameter, about 30 pieces of petals \\
\hline & & Manao2 (21) & Rose-petal and red flower, $12-15 \mathrm{~cm}$ flower diameter, about 30 pieces of petals \\
\hline & & Huaxianzi (22) & Complete type, rose-petal and red flowers, large flowers, over 30 pieces of petals \\
\hline & & Hentiangao (23) & $\begin{array}{l}\text { Rose-petal and deep red flowers, petals imbricate arrangement, 5-7 wheel, left a few pieces in } \\
\text { stamen, pistil became flat }\end{array}$ \\
\hline & & Nongxiang (24) & $\begin{array}{l}\begin{array}{l}\text { Peony and pink red flowers, about } 30 \text { pieces of petals, about } 10 \text { small petals mixed with a few golden } \\
\text { stamens }\end{array} \\
\end{array}$ \\
\hline & & \begin{tabular}{|l|} 
Shanghainvshi (25) \\
\end{tabular} & Peony and pink red flowers, $13-15 \mathrm{~cm}$ flower diameter \\
\hline & & Huopubu (26) & $\begin{array}{l}\text { Peony and red flowers, corolla dazzlingly beautiful blood red, petals imbricate; stamens numerous, } \\
\text { arranged in the } 2-6 \text { round, often at the lower part of outer filament synthetic filaments and tube, and } \\
\text { petals basally connate }\end{array}$ \\
\hline & & Moshucheng (27) & $\begin{array}{l}\text { Peony type, red flowers, floral color type is constantly changing, fire shape with white patches, best } \\
\text { peony cultivar with white medium flowering }\end{array}$ \\
\hline & & Qiududan (28) & $\begin{array}{l}\text { Peony and orange red flowers, } 10-14 \mathrm{~cm} \text { flower diameter, florescence: Late Sep. - Dec., the } \\
\text { difference with the flower peony is no white petals on the petals of autumn peony, there is no macular } \\
\text { on the leaves, while the flower peony petals have white patches, sometimes with macular leaf }\end{array}$ \\
\hline & & Hualuzhen (29) & $\begin{array}{l}\text { Peony, red with white patches flowers, petals slightly wrinkled, white patches or broad stripes, petals } \\
\text { into a few wheel arrangement; golden yellow stamens in the central; medium to large flower, growth } \\
\text { vigor, florescence: Feb. - March }\end{array}$ \\
\hline & & Kuancaidai (30) & $\begin{array}{l}\text { Peony type, milk white pink spots with red lace flowers, dark green and thick leaves, } 12-15 \mathrm{~cm} \\
\text { flower diameter, a faint fragrance }\end{array}$ \\
\hline & & Heimudan (31) & $\begin{array}{l}\text { Peony and deep red flowers, } 9-11 \mathrm{~cm} \text { flower diameter, petals from } 5 \text { to } 7 \text { round; stamens a few } \\
\text { scattered petals, florescence: Jan. - March }\end{array}$ \\
\hline & & Zhushazipao (32) & $\begin{array}{l}\text { Dark red flowers is dark purple, } 13-15 \mathrm{~cm} \text { flower diameter, petals } 40 \text { to } 50 \text { pieces, from outside to } \\
\text { inside becomes small and the clip was born in stamens between petals, pistil degradation, } \\
\text { florescence: Feb. - March }\end{array}$ \\
\hline & & Zihudie (33) & Peony and deep red flower, $8-10 \mathrm{~cm}$ flower diamter \\
\hline & & Qiaoyi (34) & Complete type, bright red, white and red-white flowers \\
\hline & & Chalisidun (35) & $\begin{array}{l}\text { Peony type to rose double type, petals have varying degrees of white patches, } 12-15 \mathrm{~cm} \text { flower } \\
\text { diameter }\end{array}$ \\
\hline & & Liujiaodahong (36) & $\begin{array}{l}\text { Obovate and larger leaves, complete type and bright red flower with } 7-8 \text { diameter and } 70-80 \text { petals } \\
\text { forming 6-7 wheels, base free petal, degeneration of male and female, florescence: May-June }\end{array}$ \\
\hline & & Zhinv (37) & $\begin{array}{l}\text { Complete type and pink red flowers, more than } 100 \text { petals spiral, } 11 \mathrm{~cm} \text { flower diameter, florescence: } \\
\text { Oct.- Feb. }\end{array}$ \\
\hline & & Meiguodahong (38) & $\begin{array}{l}\text { Complete type, deep red flower, } 10-20 \mathrm{~cm} \text { flower diameter, over } 100 \text { petals imbricate or arranged in } \\
\text { a spiral like arrangement }\end{array}$ \\
\hline & & Chidan (39) & $\begin{array}{l}\text { Completely double type and deep red flowers, over } 70 \text { petals arranged in } 8-9 \text { round, } 10 \mathrm{~cm} \text { flower } \\
\text { diameter, petals inverted tip oval, apex depression, texture thick }\end{array}$ \\
\hline & & Beila (40) & Complete type, black red flowers, large flower \\
\hline & & Liujiaoyinsi (41) & Complete type and silver-red flowers, $8-10 \mathrm{~cm}$ flower diameter \\
\hline \multirow[t]{3}{*}{ Camellia oleifera } & Hunan Province & \begin{tabular}{ll|} 
Xiang210 (42), \\
Xianglin5 (43)
\end{tabular} & $\begin{array}{l}\text { Complete type and white flowers, bigger and cyan-yellow fruits, alternate bearing, strong resistance } \\
\text { to drought, cold and west, well growth vigor }\end{array}$ \\
\hline & Guizhou Province & $\begin{array}{|lrr|}\text { NP1 } & (44), \text { NP2 } & (45), \\
\text { NP3 } & (46), & \text { NP56 } \\
(47), & \text { NP57 } & (48), \\
\text { NP58 } & (49)\end{array}$ & $\begin{array}{l}\text { Complete type and white flowers, small and cyan fruits, low-yield trees, well growth vigor, full of } \\
\text { resources as stocks of grafting Camellia japonica }\end{array}$ \\
\hline & Zhejiang Province & Changlin27 (5) & Complete type and white flowers, middle and red fruits, alternate bearing, well growth vigor \\
\hline
\end{tabular}

Genetics and Molecular Research 16 (1): gmr16019526 
Young and fully expanded leaves were collected in these provinces in May 2015 and immediately stored in plastic bags with silica gel at room temperature, until DNA extraction about one month after young collection. Only one tree per genotype was selected for collecting leaves, because the different trees are from the same genotypes by vegetative propagation. The geographic and breeding origins of all genotypes were described in Table 1.

\section{DNA extraction and SSR-PCR amplification}

Genomic DNA was extracted from $100 \mathrm{mg}$ of dry young leaves using a modified CTAB method following the procedure described by Ruan et al. (2004). DNA quality and quantification were checked by Nanodrop 2000c (Thermo scientific, Willington, CT, USA) and visualized on a 1\% agarose gel. The Nanodrop 2000 conditions and settings are that 1.5 $\mu \mathrm{L}$ gDNA solutions were dropped into the detector on the condition of gDNA type of nucleic acids module. Agarose gel running conditions are $1 \%(\mathrm{w} / \mathrm{v})$ agarose gels electrophoresis using the 0.5X TE buffer (44.5 mM Tris, $44.5 \mathrm{mM}$ boronic acid, $1 \mathrm{mM}$ EDTA, pH 8.3) on the conditions of $200 \mathrm{~V}$ for $30 \mathrm{~min}$ and visualized in a GelDoc-It2 Imaging Systems after staining with Gold View I. The genomic DNA was diluted to $20 \mathrm{ng} / \mu \mathrm{L}$ using Tris-EDTA buffer, and stored at $-20^{\circ} \mathrm{C}$ in a refrigerator with for SSR analysis.

Based on the data of RNA-seq of the leaf of C. japonica, a total of 34,833 SSRs distributed in 27,552 unigenes were identified as potential molecular markers. The primers of 138 SSR markers (Sangon Biotech, Shanghai, China) were designed by the Primer5 software based on the complementary sequence of both ends of SSR. Optimal annealing temperature per primer combination was based on the number and quality of polymorphic fragments at $56^{\circ}, 56.3^{\circ}, 56.8^{\circ}, 57.6^{\circ}, 58.6^{\circ}, 59.4^{\circ}, 59.8^{\circ}$, and $60^{\circ} \mathrm{C}$. Finally, based on amplification and reproducibility in all genotypes, a total of genic-21 SSR markers were selected for identification of genetic relationships between genotypes used in this study.

A $20-\mu \mathrm{L}$ reaction volume was used for polymerase chain reaction, which contained $2 \mu \mathrm{L}$ 10X PCR buffer (with $1.6 \mathrm{mM} \mathrm{Mg}^{2+}$, TaKaRa, Dalian, China), $0.4 \mathrm{nmol}$ dNTP (Sangon Biotech, Shanghai, China), 0.5 U Taq polymerase (Takara, Dalian, China), $13.4 \mu \mathrm{L}$ ultrapure water, $10 \mathrm{pmol}$ each forward and reverse primer, and $40 \mathrm{ng}$ gDNA template. Amplification was performed in a thermocycler (Bio-Rad C1000 Touch TM) with a 4-min initial denaturation at $94^{\circ} \mathrm{C}$, followed by 35 cycles at $94^{\circ} \mathrm{C}$ for $30 \mathrm{~s}$, annealing at $58^{\circ} \mathrm{C}$ for $30 \mathrm{~s}$, and an extension at $72^{\circ} \mathrm{C}$ for $30 \mathrm{~s}$. A final extension was performed at $72^{\circ} \mathrm{C}$ for $10 \mathrm{~min}$ and then the product was stored at $4^{\circ} \mathrm{C}$. The reactions were then placed at $-20^{\circ} \mathrm{C}$ until gel analysis. The PCR products were loaded onto $8 \%$ polyacrylamide non-denaturing gels, and separated by electrophoresis at $150 \mathrm{~V}$ for $9 \mathrm{~h}$ using a Hoefer SE600 Ruby Standard Vertical Electrophoresis Unit (Amersham Biosciences, Piscataway, NJ, USA) (Lin et al., 2015) and detected by silver nitrate staining. A 1-kb size marker was used as a DNA ladder (Sangon Biotech, Shanghai, China) to estimate the SSR allele band size (Chen et al., 2015).

\section{Data analysis}

Gels were scored in a binary format, according to whether a band was present (1) or not (0) by the methods of Chen et al. (2015) and Abdessemed et al. (2015). The genetic diversity of a population was evaluated by the average number of the alleles shared by the individuals in each population and the percentage of polymorphisms (following Lai et al.,

Genetics and Molecular Research 16 (1): gmr16019526 
2015). The polymorphism information content (PIC) was calculated by the formula $P I C=$

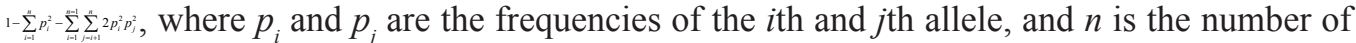
alleles ( $\mathrm{Li}$ et al., 2015). The relative frequency of the $j$ th allele for the $i$ th locus is added across all the alleles for the locus over all genotypes. The Dice coefficient (DC) between pairs of genotypes was measured by the DICE similarity coefficient (Dice, 1945) based on the SSR data using the SIMQUAL module of NTSYSpc ver. 2.02 (Rohlf, 2000).

POPGENE 1.32 was used to evaluate genetic diversity of the different groups, by calculating seven different genetic indices: the number of alleles $\left(N_{\mathrm{A}}\right)$, the effective number of alleles $\left(N_{\mathrm{E}}\right)$, Nei's gene diversity $(H)$, Shannon's information index $(I)$, the number of polymorphic alleles $\left(N_{\mathrm{p}}\right)$, the percentage of polymorphic loci $(P)$.

\section{RESULTS}

\section{SSR analysis}

Twenty-one SSR markers used generated 438 alleles, 436 (99.5\%) of which were polymorphic. The number of alleles per SSR marker ranged from 8 for CJ1030 and CJ1066 to 30 for CJ1100, with an average of 20.85 alleles per locus (Table 2). The PIC values per SSR marker ranged from 0.1800 for CJ2020 to 0.4336 for CJ2051, with an average of 0.3406 per locus. Representative polyacrylamide gel electrophoresis profiles of PCR products amplified using the SSR marker of CJ1066 was shown in Figure 2.

Table 2. Locus and numbers of SSR markers generated for all genotypes.

\begin{tabular}{|c|c|c|c|c|c|c|}
\hline Locus & Forward $(\mathrm{F})$ and reverse $(\mathrm{R})$ primers & $\mathrm{AT}\left({ }^{\circ} \mathrm{C}\right)$ & NB & NPB & Polymorphism & $P I C$ \\
\hline CJ1030 & $\begin{array}{l}\text { F: AATGCAGTCAAACGAAAGGG } \\
\text { R: TGCTGGAGGAATGGATTTTC }\end{array}$ & 58 & 30 & 30 & $100 \%$ & 0.3737 \\
\hline$\overline{\mathrm{CJ} 1031}$ & $\begin{array}{l}\text { F: GGGAACAAAATGATGCGATTA } \\
\text { R: AATGGTGGTGTTGTTGGGTT }\end{array}$ & 58 & 21 & 21 & $100 \%$ & 0.3783 \\
\hline $\begin{array}{l}\mathrm{CJ} 1056 \\
\end{array}$ & $\begin{array}{l}\text { F: AAGGGCGTCTCCAATTTGTC } \\
\text { R: CGGAAGAAGAGACGGTGAAG }\end{array}$ & 58 & 26 & 26 & $100 \%$ & 0.3616 \\
\hline$\overline{\mathrm{CJ} 1057}$ & $\begin{array}{l}\text { F: AACCACACACACAACAATCACTC } \\
\text { R: TTCACCCCAGAACTGGAAAC }\end{array}$ & 58 & 28 & 28 & $100 \%$ & 0.2840 \\
\hline $\begin{array}{lll}\text { CJ1066 } \\
\end{array}$ & $\begin{array}{l}\text { F: GGATTTCAGATGCAGACCTTG } \\
\text { R: TTTGGGAAAACTAAAGCGGA }\end{array}$ & 58 & 30 & 29 & $97 \%$ & 0.3012 \\
\hline 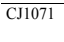 & $\begin{array}{l}\text { F: ACAATTGGAGGATGAGTGCC } \\
\text { R: AGAGAGTTCCTCCCTCCGAC }\end{array}$ & 58 & 21 & 20 & $95 \%$ & 0.3876 \\
\hline 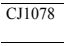 & $\begin{array}{l}\text { F: GCAGCGACAGTTCTGTTGAA } \\
\text { R: CACCACATCCCCTTCCTCTA }\end{array}$ & 58 & 23 & 23 & $100 \%$ & 0.2617 \\
\hline$\overline{C J 1100}$ & $\begin{array}{l}\text { F: AAATGGGAAAGATTGGGGAG } \\
\text { R: GCCTCTTTCTTCAATTCCCTG }\end{array}$ & 58 & 8 & 8 & $100 \%$ & 0.3488 \\
\hline 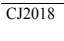 & $\begin{array}{l}\text { F: CCGAGCTCTCAATATCAGGC } \\
\text { R: TTCAGGGAAAGGGAAGGAGT }\end{array}$ & 58 & 22 & 22 & $100 \%$ & 0.1857 \\
\hline CJ2020 & $\begin{array}{l}\text { F: CACCACGAAGTGATCGTGTC } \\
\text { R: ACAAATCGGTCGTGAAGGTC }\end{array}$ & 58 & 19 & 19 & $100 \%$ & 0.1800 \\
\hline $\begin{array}{l}\mathrm{C} 2021 \\
-1\end{array}$ & $\begin{array}{l}\text { F: GTCATCGAGTGGTGGTGATG } \\
\text { R: CACAGGGACAGTGTCGAGAA }\end{array}$ & 58 & 15 & 15 & $100 \%$ & 0.3263 \\
\hline $\begin{array}{l}\mathrm{CJ} 2024 \\
-1\end{array}$ & $\begin{array}{l}\text { F: TGGCTACCTTCTTCGTTGCT } \\
\text { R: CCATTCTCGACGAATCCAGT }\end{array}$ & 58 & 15 & 15 & $100 \%$ & 0.3860 \\
\hline 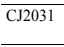 & $\begin{array}{l}\text { F: ACTGTGGGACAAAGCGAGTT } \\
\text { R: GGTCTGACGAACCCATTCAC }\end{array}$ & 58 & 21 & 21 & $100 \%$ & 0.4238 \\
\hline$\overline{\mathrm{CJ} 2033}$ & $\begin{array}{l}\text { F: GAAATGGCGATTATGGCAAC } \\
\text { R: CCCAACGAAACGATAACAGG }\end{array}$ & 58 & 18 & 18 & $100 \%$ & 0.4127 \\
\hline $\begin{array}{ll}\mathrm{CJ} 2036 \\
\end{array}$ & $\begin{array}{l}\text { F: GCTCGTAGGTGTGTTGGGTT } \\
\text { R: CAGCCACTTTACCTCCCAAA }\end{array}$ & 58 & 12 & 12 & $100 \%$ & 0.3119 \\
\hline 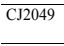 & $\begin{array}{l}\text { F: CACAAGGAGGGGGTACGTTA } \\
\text { R: CACCTTCCACAGAGGGAGAC }\end{array}$ & 58 & 28 & 28 & $100 \%$ & 0.2161 \\
\hline $\begin{array}{l}\mathrm{CJ} 2050 \\
-1\end{array}$ & $\begin{array}{l}\text { F: TAAAGCTTCCCATCAAACGC } \\
\text { R: CAGAGGAACAGTCGAGGAGG }\end{array}$ & 58 & 13 & 13 & $100 \%$ & 0.4019 \\
\hline $\begin{array}{l}\mathrm{CJ} 2051 \\
\end{array}$ & $\begin{array}{l}\text { F: CGTGCCTGCATTGCTAATAA } \\
\text { R: GTACCAGTAACTGCGGGGAA }\end{array}$ & 58 & 18 & 18 & $100 \%$ & 0.4336 \\
\hline 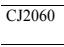 & $\begin{array}{l}\text { F: CGTAACAGCAAGCGACTGAG } \\
\text { R: GTGACGAACCGAAACGTACA }\end{array}$ & 58 & 27 & 27 & $100 \%$ & 0.4096 \\
\hline 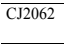 & $\begin{array}{l}\text { F: TGCCATAAGACGAACCAGAA } \\
\text { R: CCTACTCTCCGCCAGTCTCC }\end{array}$ & 58 & 15 & 15 & $100 \%$ & 0.3730 \\
\hline$\overline{\mathrm{CJ} 2066}$ & $\begin{array}{l}\text { F: CACACACACACAAACGCAAA } \\
\text { R: GGTGATGATAGGAAAATGATTGA }\end{array}$ & 58 & 28 & 28 & $100 \%$ & 0.3955 \\
\hline
\end{tabular}

AT: annealing temperature; NB: the number of total bands; NPB: the number of polymorphic bands; PIC: percentage of polymorphic loci.

Genetics and Molecular Research 16 (1): gmr16019526 


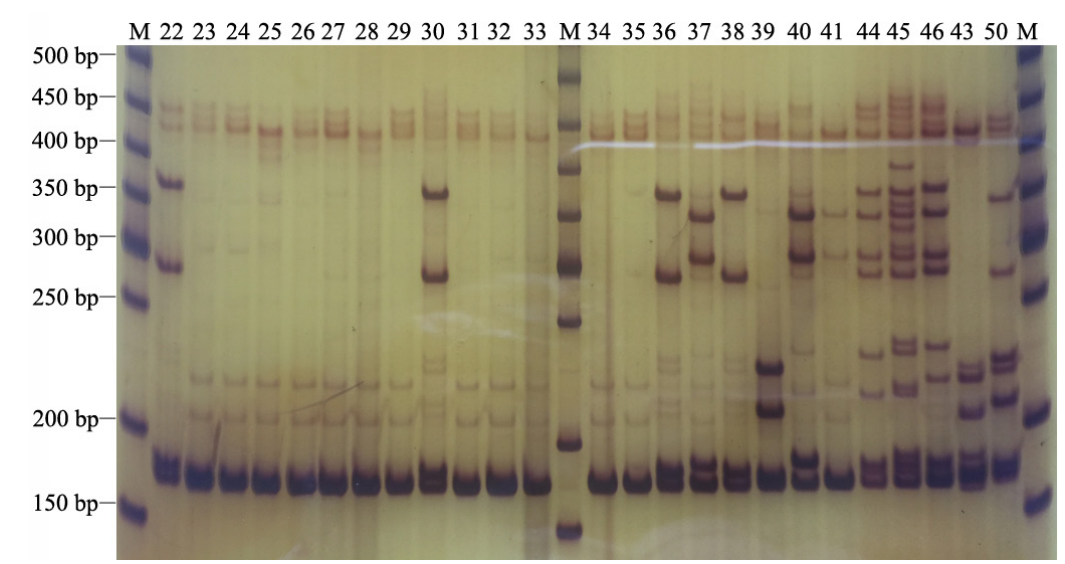

Figure 2. Representative polyacrylamide gel electrophoresis profiles of PCR products amplified using the SSR marker of CJ1066. Number of 22-41 indicated different genotypes of Camellia japonica and 43-46 and 50 for genotypes of Camellia oleifera in Table 1.

\section{Genetic diversity of Camellia cultivars}

DCs between each pair of 41 C. japonica cultivars ranged from 0.17 to 0.98 , with a mean of $0.41 \pm 0.13$. DCs between all pairs of 50 genotypes ranged from 0.13 to 0.98 , with a mean of $0.38 \pm 0.13$.

Genetic diversities within groups (except Group IV in Figure 3) were assessed using seven genetic parameters (Table 3). For C. japonica, the group II cultivars from Zhejiang Province had higher genetic diversity than the group I cultivars from Yunnan Province (Table 3). Group III consisted of nine genotypes of $C$. oleifera showed higher genetic diversity than group I of 10 genotypes and group II of 30 genotypes of $C$. japonica (Table 3). For example, $N_{\mathrm{E}}$ of group III was 1.32 , and was 1.25 and 1.18 for groups II and I, respectively. $H$ of group III was 0.21 , and was 0.17 and 0.11 for groups II and I, respectively. $N$ p of group III was 272 , and was 243 and 71 for groups II and I. PIC of group III was 0.40 , and was 0.34 and 0.33 for groups II and I, respectively.

\section{Cluster analysis}

At a DC of 0.351, 50 genotypes were clustered into three major groups (I, II and III) except for cultivar 'Damanao' from Yunnan Province (IV) (Figure 2). The cluster analysis showed groupings of genotypes, which agreed with their taxonomic classification and geographic origin. Cultivar 'Damaonao' was a large tree with flowers of composite color, and showed the most genetic distance from other $C$. japonica cultivars and $C$. oleifera genotypes in the cluster analysis. In contrast, all other genotypes had single-colored flowers, and most of them were shrubs or small trees.

Group I included 10 C. japonica cultivars from Yunnan Province. At a DC of 0.648, Group I was divided into three subgroups: Group Ia consisted of four cultivars 'Jinxinfurong', 'Dalidiechi', 'Dalicha', and 'Xuejiao', which had semi-double and peony type flowers. Group Ib included five cultivars 'Songzikui', 'Shizitou', 'Dandinghe', 'Fengshancha', and 'Dazipao', which had red, purple red or deep red flowers. The remaining 'Zaodudan' cultivar had peonytype red flowers and was in Group Ic. 


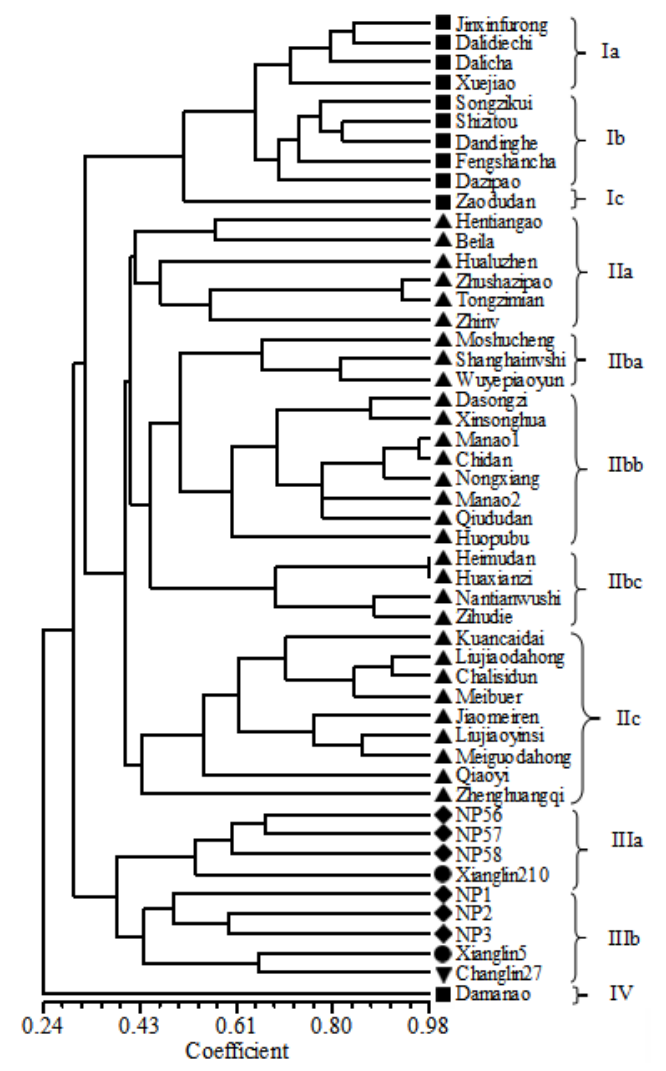

Figure 3. Dendrogram of 50 genotypes revealed by cluster analysis of genetic similarity estimates generated by Dice coefficient based on 438 alleles from 21 SSR markers. Square = geographic location is Yunnan Province; up arrowhead = geographic location is Zhejiang Province; diamond = geographic location is Guizhou Province; circle $=$ geographic location is Hunan Province; down arrowhead = geographic location is Zhejjiang Province.

Table 3. Genetic diversity of Camellia japonica and Camellia oleifera groups.

\begin{tabular}{l|c|c|c|c|c|c|c|c}
\hline Group & $N$ & $N_{\mathrm{a}}$ & $N_{\mathrm{e}}$ & $H$ & $I$ & $N_{\mathrm{p}}$ & $P$ & $P I C$ \\
\hline $\mathrm{I}^{\mathrm{i}}$ & 10 & 1.4018 & 1.1873 & 0.1148 & 0.1786 & 71 & $40.18 \%$ & 0.3345 \\
\hline $\mathrm{II}^{\mathrm{j}}$ & 30 & 1.7443 & 1.2514 & 0.1651 & 0.2689 & 243 & $74.43 \%$ & 0.3361 \\
\hline $\mathrm{III}^{\mathrm{k}}$ & 9 & 1.7877 & 1.3246 & 0.2089 & 0.3324 & 272 & $78.77 \%$ & 0.4014 \\
\hline
\end{tabular}

$N$ : the number of genotypes; $N_{\mathrm{A}}$ : observed number of alleles; $N_{\mathrm{E}}$ : effective number of alleles; $H$ : Nei's gene diversity; $I$ : Shannon's information index; $N_{\mathrm{p}}$ : the number of polymorphic alleles; $P$ : percentage of polymorphic loci; PIC: polymorphism information content; ${ }^{\mathrm{i}}$ group I consisted of 10 cultivars of $C$. japonica from Yunnan Province; ${ }^{j}$ group II consisted of 30 cultivars of $C$. japonica from Zhejiang Province; ${ }^{k}$ group III consisted of nine genotypes of C. oleifera.

Group II consisted of 30 C. japonica cultivars from Zhejiang Province and shared an identical genetic background. This group was divided into three subgroups at a level of DC of 0.39. Group IIa included six cultivars 'Hentiangao', 'Beila', 'Hualuzhen', 'Zhushazipao', 'Tongzimian', and 'Zhinv'. 'Tongzimian' and 'Zhushazipao' are both shrubs or small trees and were clustered together. 'Huanluzhen' has red flower with white patches, and is different to other three cultivars with single-color flower ('Zhushazipao', 'Tongziman' and 'Zhinv').

Genetics and Molecular Research 16 (1): gmr16019526 
Group IIb consisted of 15 cultivars, which is further divided into three sub-subgroups based on a DC of 0.57. The cultivars of the sub-subgroup Ilba have similar flower color, but different flower types (semidouble type for 'Wuyepiaoyun' and peony type for 'Moshucheng' and 'Shanghainvshi'). In the sub-subgroup IIbb, the two cultivars of 'Dasongzi' and 'Xinsonghua' with semi-double and red flowers were clustered together; the five cultivars of 'Manaol', 'Chidan', 'Nongxiang', 'Manao2', and 'Qiududan' clustered together and had similar flower color but different floral types (rose-petal type for 'Manao1' and 'Manao2', complete type for 'Chidan' and peony type for 'Nongxiang' and 'Qiududan'). 'Huopubu', which is a shrub or tree, showed the most divergent genetic distance in this sub-subgroup. In the sub-subgroup IIbc, two cultivars of 'Heimudan' and 'Huaxianzi' clustered together had similar flower color, but their floral types differed, e.g., rose type for 'Huaxianzi' and peony type for 'Heimudan'; the two cultivars of 'Nantianwushi' and 'Zihudie' had similar flower color and floral type, and clustered together.

Group IIc consisted of nine cultivars, the 'Zhenghuangqi' showed the most divergent genetic distance in this subgroup and had yellow flowers, which differed from the flower colors of the remaining eight cultivars. The 'Qiaoyi' cultivar had different colored flowers, such as pure red, pure pink red, pure white, and a composite of red and white. The three cultivars of 'Jiaomeiren', 'Liujiaoyinsi' and 'Meiguodahong' with similar flower color clustered together. The two cultivars of 'Liujiaodahong' and 'Chalisidun' had similar floral type and color, and were clustered into one branch in this subgroup; the two cultivars 'Meibuer' and 'Kuancaidai' had white flowers with red-trimmed lace, and also clustered into this branch based on the DC of 0.68.

At a DC of 0.39 , group III with nine $C$. oleifera genotypes was divided into two subgroups: Group IIIa consisted of four genotypes, three of which were from Guizhou Province, and the remaining cultivar 'Xianglin210' was from Hunan Province. Group IIIb consisted of five genotypes, three of which 'NP1', 'NP2', 'NP3' from Guizhou Province were clustered into a branch, and the remaining two cultivars of 'Xianglin5' and 'Changlin27' from Hunan and Jiangxi provinces were clustered into another branch.

\section{DISCUSSION}

Results revealed for the first time the genetic relationship of genotypes between $C$. japonica and $C$. oleifera, which provides potential determine correlations between genetic relationship and graft compatibility among scions of $C$. japonica and $C$. oleifera. In addition, the SSR profiles in this study clearly identified different genotypes of $C$. japonica in southern China, and showed potential to authenticate cultivars, which are widely used for gardening green. This could improve $C$. japonica germplasm management. There are three reports on SSR markers for $C$. japonica, but 1 ) only three SSR markers for $C$. japonica were developed and used for genotyping 22 individuals from a Japanese population (Ueno and Tsumura, 2009); 2) Jia et al. (2014) only reported the development of 15 genic-SSR markers for cultivar 'Huashou' of $C$. oleifera, and its ability to successfully amplify PCR products with expected size and polymorphisms in 15 cultivars of $C$. japonica and 18 cultivars of $C$. oleifera, there is no report on genetic relationships among different cultivars, and there cultivars are different from the genotypes in this study; and 3) Jia et al. (2015) only reported cross-species transferability rates of 52-genic SSR markers in C. chekangoleosa and C. japonica based on SSR markers, which was developed from 20 cultivars of C. oleifera. These SSR markers and cultivars of C. oleifera are also different from the genotypes in this study, and there is also no report on genetic relationship between cultivars of $C$. oleifera and $C$. japonica.

Genetics and Molecular Research 16 (1): gmr16019526 
In this study, the genotypes are from two species of Camellia. The SSR profiles of the genotypes showed a high polymorphism for Camellia cultivars and for all genotypes. The $N_{\mathrm{A}}$ per SSR marker in this study is higher than the $N_{\mathrm{A}}$ ranging from 2 to 13 in the report of Ueno and Tsumura (2009), in which three SSR markers were used to genotype 22 individuals within a $C$. japonica population. High mean bands per SSR primer combination in this study could be generated from materials with high genetic or geographic differences. In our study, we repeated three amplifications and obtained identical results for primer combinations that generated a high number of alleles (e.g., CJ1030 and CJ1066).

Knowledge of genetic relationships is a key factor for managing genetic resources in a successful breeding program (Amar et al., 2011). Microsatellite genotyping can allow unambiguous identification of germplasm (Dominguez-Garcia et al., 2012; Muzzalupo et al., 2014; Mousavi et al., 2014). Because of their high discriminatory power and typically straight forward interpretation (Taniguchi et al., 2014; Jia et al., 2015), SSR markers have been becoming the preferred choice for genetic identification of Camellia germplasm. Couselo et al. (2010) used 14 SSR markers to differentiate two groups of ancient specimens of $C$. japonica grown in gardens of Galicia and Northern Portugal.

In this study, the results of cluster analysis based on SSR profiles are in accordance with their genetic and geographic origin. Twenty-one SSR markers clearly distinguish $39 C$. japonica cultivars (except for 'Heimudan' and 'Huaxianzi') and nine genotypes of C. oleifera. The $C$. japonica cultivars from Yunnan and Zhejiang provinces were clustered into different groups, respectively, in agreement with their geographic origin in the cluster analysis. The genotypes of $C$. oleifera from three provinces (Guizhou, Hunan and Jiangxi provinces) were clustered into one group, indicating genetic accordance. Although the studied cultivars of $C$. japonica and genotypes of $C$. oleifera are from the limited geographic ranges, there is no report on genetic relationships among them using SSR markers in previous studies. The cultivars of $C$. japonica in this study have been planted widely in southern China, grow well and have many desirable agronomic traits, such as bigger and different color flowers (Table 1); the genotypes of $C$. oleifera have been widely planted in Guizhou Province, which provided a plenty of low-yield trees as stocks for grafts of scions of $C$. japonica. Of course, a future study with a greater number of samples from a broader geographic range, and including any wild cultivars would be quite interesting.

In our analysis, the 'Damanao' cultivar clusters into a single group beside both the $C$. japonica group and the $C$. oleifera group, indicating this cultivar may be selected from other subgenus of the Camellia genus. In Group III, two C. oleifera cultivars 'Xianglin210' and 'Xianglin5' are from the same Hunan province, but the former clusters into one subgroup with three genotypes from Guizhou Province, and the latter appears in subgroup including 'Changlin27' from Jiangxi Province. These indicate the 'Xianglin210' cultivar may be selected from the materials growing in region of Hunan Province nearby Guizhou Province, and the 'Xianglin5' was selected from materials nearby Jiangxi Province.

Molecular markers such as SSR and ISSR can be useful tools to identify and authenticate cultivars (Li et al., 2009; Couselo et al., 2010). Our data revealed that there are two main problems with nomenclature in the C. japonica germplasm we studied: 1) some cultivars are the same but have different names, and 2) some cultivars have the same name but are genetically distinct. On the one hand, the DC of 0.98 between 'Heimudan' and 'Huaxianzi' suggests they are likely to be the same cultivar, combining with their similar morphological traits; but they were given different names when selected and bred in China. There was also no

Genetics and Molecular Research 16 (1): gmr16019526 
obvious distinction between 'Manao1' and 'Chidan' ( $\mathrm{DC}=0.96)$, between 'Zhushazipao' and 'Tongzimian' ( $\mathrm{DC}=0.93)$, and between 'Liujiaodahong' and 'Chalisidun' $(\mathrm{DC}=0.91)$; these paired cultivars originate from Zhejiang Province and share a common genetic background and morphological traits. This nomenclature may have resulted from unknown pedigrees and mis-registration of exchange materials with each other, or could have arisen from intentional false naming for commercial gain. On the other hand, three cultivars of 'Manao1', 'Manao2' and 'Damanao' have the same name of 'Manao', but they clustered into different groups, II and IV, respectively (DC between 'Manao1' and 'Damanao' $=0.25$, and 0.20 between 'Manao2' and 'Damanao'). Cultivar 'Damanao' was selected in Yunnan Province, and the two cultivars of 'Manao1' and 'Manao2' are bred in Zhejiang Province. Resolving these inconsistencies in genetic identification will help to properly collect and conserve Camellia germplasm, and allow a true-to-type verification of material on the commercial market.

The tall tree crown $C$. japonica has a growth period of only 10-20 years, the low-yield but long-lived trees of $C$. oleifera have been used as stocks for grafting scions of $C$. japonica with different size and color of flowers (Zhang et al., 2015). This graft not only could gain tall crown and beautiful $C$. japonica flowers at 2-3 years after grafts, but also could efficiency utilize the low-yield trees of $C$. oleifera. However, grafting compatibility between stocks and scions are important for grafting success (Yan et al., 2012), which is related to their genetic relationships (Belaj et al., 2007).

\section{Cultivated and wild olives show very good grafting affinity.}

In this study, the SSR profiles were first used to identify genetic relationships between genotypes of $C$. japonica and $C$. oleifera, and provide a potential strategy for improving grafting success between stocks of $C$. oleifera and scions of $C$. japonica. Based on their genetic relationships, different grafting combinations could be recommended, such as scions of 'Meibuer' with stocks of NP56 (DC $=0.48)$ (Figure 1C), scions of 'Huopubu' with stocks of 'NP1' (DC = 0.46) (Figure 1D), scions of 'Chalisidun' with stocks of 'NP56' (DC = 0.45) (Figure 1E), scions of 'Liujiaodahong' with stocks of 'NP56' $(\mathrm{DC}=0.44)$ (Figure 1F), scions of 'Shizitou' with stocks of 'NP56' (DC = 0.43), scions of 'Kuancaidai' with stocks of 'NP56' ( $\mathrm{DC}=0.42)$, scions of 'Zhenghuangqi' with stocks of 'NP1' $(\mathrm{DC}=0.42)$, scions of 'Heimudan' with stocks of 'NP1' (DC = 0.41) and scions of 'Huaxianzi' with stocks of 'NP1' (DC = 0.41). For example, the survival rate of graft between scions of 'Meibuer' with stocks of 'NP56' was about $84.3 \%(\mathrm{DC}=0.48)$. And, it is only about $46.8 \%$ between scions of 'Hengtiangao' with stocks of 'Xianglin5' $(\mathrm{DC}=0.23)$, most of scions and stocks will be dead at 4 years after grafting (Ruan CJ, Liu SH, Du W and Mopper S, unpublished data).

\section{Conflicts of interest}

The authors declare no conflict of interest.

\section{ACKNOWLEDGMENTS}

Research supported by the Keystone Project of the Agriculture Science and Technology Research Item of Guizhou Province [Qiankehezhicheng \#(2016)2519 and \#(2013)201], the Fundamental Research Funds for the Central Universities (\#DC201501070102) and the Key Project of State Ethnic Affairs Commission of the People's Republic of China (\#0908210005).

Genetics and Molecular Research 16 (1): gmr16019526 


\section{REFERENCES}

Abdessemed S, Muzzalupo I and Benbouza H (2015). Assessment of genetic diversity among Algerian olive (Olea europaea L.) cultivars using SSR marker. Sci. Hortic. (Amsterdam) 192: 10-20. http://dx.doi.org/10.1016/j.scienta.2015.05.015

Ali ML, Rajewski JF, Baenziger PS, Gill KS, et al. (2008). Assessment of genetic diversity and relationship among a collection of US sweet sorghum germplasm by SSR markers. Mol. Breed. 21: 497-509. http://dx.doi.org/10.1007/ s11032-007-9149-Z

Amar MH, Biswas MK, Zhang Z and Guo WW (2011). Exploitation of SSR, SRAP and CAPS-SNP markers for genetic diversity of Citrus germplasm collection. Sci. Hortic. (Amsterdam) 128: 220-227. http://dx.doi.org/10.1016/j. scienta.2011.01.021

Belaj A, Muñoz-Diez C, Baldoni L, Porceddu A, et al. (2007). Genetic diversity and population structure of wild olives from the North-Western Mediterranean assessed by SSR markers. Ann. Bot. (Lond.) 100: 449-458. http://dx.doi. org $/ 10.1093 / \mathrm{aob} / \mathrm{mcm} 132$

Chen H, Qiao L, Wang L, Wang S, et al. (2015). Assessment of genetic diversity and population structure of mung bean (Vigna radiata) germplasm using EST-based and genomic SSR markers. Gene 566: 175-183. http://dx.doi. org/10.1016/j.gene.2015.04.043

Couselo JL, Vela P, Salinero C and Sainz MJ (2010). Characterization and differentiation of old Camellia japonica cultivars using simple sequence repeat (SSRs) as genetic markers. 2010 International Camellia Congress, Kurume.

Dice IR (1945). Measures of the amount of ecologic association between species. Ecology 26: 297-302. http://dx.doi. org/10.2307/1932409

Ding J, Ruan CJ, Guan Y, Shan JY, et al. (2016). Characterization and identification of ISSR markers associated with oil content in sea buckthorn berries. Genet. Mol. Res. 15: gmr.15038278.

Dominguez-Garcia MC, Laib M, De la Rosa R and Belaj A (2012). Characterisation and identification of olive cultivars from North-eastern Algeria using molecular markers. J. Hortic. Sci. Biotechnol. 87: 95-100. http://dx.doi.org/10.10 $\underline{80 / 14620316.2012 .11512837}$

Estevinho LM, Feás X, Salinero C, Mansilla JP, et al. (2012). Antimicrobial properties of Camellia oleifera oil. The 16th International Electronic Conference on Synthetic organic Chemistry (ECSOC-16), 30 November 2012.

Fufa H, Baenziger PS, Beecher BS, Dweikat I, et al. (2005). Comparison of phenotypic and molecular marker-based classifications of hard red winter wheat cultivars. Euphytica 145: 133-146. http://dx.doi.org/10.1007/s10681-005-0626-3

Gurcan K, Ocal N, Yilmazd KU, Ullah S, et al. (2015). Evaluation of Turkish apricot germplasm using SSR markers: Genetic diversity assessment and search for Plum pox virus resistance alleles. Sci. Hortic. (Amsterdam) 193: 155164. http://dx.doi.org/10.1016/j.scienta.2015.07.012

Hajmansoor S, Bihamta MR and Alisoltani A (2013). Genetic diversity among and within Iranian and non-Iranian barely (Hordeum vulgare L.) genotypes using SSR and storage proteins markers. Biochem. Syst. Ecol. 46: 7-17. http:// dx.doi.org/10.1016/j.bse.2012.08.001

Jia BG, Lin Q, Feng YZ, Hu XY, et al. (2015). Development and cross-species transferability of unigene-derived microsatellite markers in an edible oil woody plant, Camellia oleifera (Theaceae). Genet. Mol. Res. 14: 6906-6916. http://dx.doi.org/10.4238/2015.June.18.33

Jia BQ, Lin L, Zhang X, Tan X, et al. (2014). Development of 15 genic-SSR markers in oil-tea tree (Camellia oleifera) based on transcriptome sequencing. Genetika 46: 789-797. http://dx.doi.org/10.2298/GENSR1403789J

Jin XC (2012). Bioactivities of water-soluble polysaccharides from fruit shell of Camellia oleifera Abel: antitumor and antioxidant activities. Carbohydr. Polym. 87: 2198-2201. http://dx.doi.org/10.1016/j.carbpol.2011.10.047

Jo KM, Jo Y, Chu H, Lian S, et al. (2015). Development of EST-derived SSR markers using next-generation sequencing to reveal the genetic diversity of 50 chrysanthemum cultivars. Biochem. Syst. Ecol. 60: 37-45. http://dx.doi. org/10.1016/j.bse.2015.03.002

Lai JJ, Li ZZ, Man YP, Lei R, et al. (2015). Genetic diversity of five wild Actinidia arguta populations native to China as revealed by SSR markers. Sci. Hortic. (Amsterdam) 191: 101-107. http://dx.doi.org/10.1016/j.scienta.2015.05.004

Lai Y, Wang PX, Fan GQ, Si EJ, et al. (2013). Genetic diversity and association analysis using SSR markers in barley. Zhongguo Nong Ye Ke Xue 46: 233-242.

Lee CP, Shih PH, Hsu CL and Yen GC (2007). Hepatoprotection of tea seed oil (Camellia oleifera Abel.) against CCl4induced oxidative damage in rats. Food Chem. Toxicol. 45: 888-895. http://dx.doi.org/10.1016/j.fct.2006.11.007

LiC, Ling Q, Ge C, YeZ, et al. (2015). Transcriptome characterization and SSR discovery in large-scale loach Paramisgurnus dabryanus (Cobitidae, Cypriniformes). Gene 557: 201-208.http://dx.doi.org/10.1016/j.gene.2014.12.034

Li H, Ruan CJ and Da Silva JAT (2009). Identification and genetic relationship based on ISSR analysis in a germplasm collection of sea buckthorn (Hippophae L.) from China and other countries. Sci. Hortic. (Amsterdam) 123: 263-271. http://dx.doi.org/10.1016/j.scienta.2009.08.007

Lin WJ, Vun YT, Yoong SY, Kenneth FR, et al. (2015). Micropropagation and protein profile analysis by SDS-PAGE of

Genetics and Molecular Research 16 (1): gmr16019526 
Gracilaria changii (Rhodophyta, Solieriaceae). Aquac. Report 1: 10-14.

Ma JQ, Zhou YH, Ma CL, Yao MZ, et al. (2010). Identification and characterization of 74 novel polymorphic ESTSSR markers in the tea plant, Camellia sinensis (Theaceae). Am. J. Bot. 97: e153-e156. http://dx.doi.org/10.3732/ ajb. 1000376

Mahjbi A, Oueslati A, Baraket G, Salhi-Hannachi A, et al. (2016). Assessment of genetic diversity of Tunisian orange, Citrus sinensis (L.) Osbeck using microsatellite (SSR) markers. Genet. Mol. Res. 15: gmr6564. http://dx.doi. org/10.4238/gmr. 15026564

Mornkham T, Wangsomnuk PP, Mo XC, Francisco FO, et al. (2016). Development and characterization of novel EST-SSR markers and their application for genetic diversity analysis of Jerusalem artichoke (Helianthus tuberosus L.). Genet. Mol. Res. 15: gmr15048857. http://dx.doi.org/10.4238/gmr15048857

Mousavi S, Mazinani MH, Arzani K, Ydollahi A, et al. (2014). Molecular and morphological characterization of Golestan (Iran) olive ecotypes provides evidence for the presence of promising genotypes. Genet. Resour. Crop Evol. 61: 775785. http://dx.doi.org/10.1007/s10722-013-0071-4

Muzzalupo I, Vendramin GG and Chiappetta A (2014). Genetic biodiversity of Italian olives (Olea europaea) germplasm analyzed by SSR markers. Sci. World J. 2014: 296590.http://dx.doi.org/10.1155/2014/296590

Neiva DS, Melo Júnior AF, Oliveira DA, Royo VA, et al. (2016). Acrocomia emensis (Arecaceae) genetic structure and diversity using SSR molecular markers. Genet. Mol. Res. 15: gmr7785.http://dx.doi.org/10.4238/gmr.15017785

Peng M, Guan F, Tao L, Li RQ, et al. (2015). Analysis of genetic relationship on Amygdalus mira (Koehne) Ricker with other peach species using simple sequence repeat (SSR). Biochem. Syst. Ecol. 62: 98-105. http://dx.doi.org/10.1016/j. bse.2015.06.026

Queiroz A, Assuncao A, Ramadas I, Viegas W, et al. (2015). Molecular characterization of Portuguese pear landraces (Pyrus communis L.) using SSR markers. Sci. Hortic. (Amsterdam) 183: 72-76. http://dx.doi.org/10.1016/j. scienta.2014.11.016

Rohlf FJ (2000). NTSYS-pc: numerical taxonomy and multivariate analysis system. Version 2.1 Manual. Exeter Software, Setauket.

Ruan CJ, Qin P, Zheng JW and He ZX (2004). Genetic relationships among some cultivars of sea buckthorn from China, Russia and Mongolia based on RAPD analysis. Sci. Hortic. (Amsterdam) 101: 417-426. http://dx.doi.org/10.1016/j. scienta.2003.11.013

Salinero C, Feás X, Mansilla JP, Seijas JA, et al. (2012). ${ }^{1} \mathrm{H}$-nuclear magnetic resonance analysis of the triacylglyceride composition of cold-pressed oil from Camellia japonica. Molecules 17: 6716-6727. http://dx.doi.org/10.3390/ molecules 17066716

Tan LQ, Wang LY, Wei K, Zhang CC, et al. (2013). Floral transcriptome sequencing for SSR marker development and linkage map construction in the tea plant (Camellia sinensis). PLoS One 8: e81611.http://dx.doi.org/10.1371/journal. pone. 0081611

Taniguchi F, Kimura K, Saba T, Ogino A, et al. (2014). Worldwide core collections of tea (Camellia sinensis) based on SSR markers. Tree Genet. Genomes 10: 1555-1565. http://dx.doi.org/10.1007/s11295-014-0779-0

Tholstrup T, Ehnholm C, Jauhiainen M, Petersen M, et al. (2004). Effects of medium-chain fatty acids and oleic acid on blood lipids, lipoproteins, glucose, insulin, and lipid transfer protein activities. Am. J. Clin. Nutr. 79: 564-569.

Ueno S and Tsumura Y (2009). Development of microsatellite and amplicon length polymorphism markers for Camellia japonica L. from tea plant (Camellia sinensis) expressed sequence tags. Mol. Ecol. Resour. 9: 814-816. http://dx.doi. org/10.1111/j.1755-0998.2008.02316.x

Ujihara T, Ohta R, Hayashi N, Kohata K, et al. (2009). Identification of Japanese and chinese green tea cultivars by using simple sequence repeat markers to encourage proper labeling. Biosci. Biotechnol. Biochem. 73: 15-20. http://dx.doi. org $/ 10.1271 / \mathrm{bbb} .80248$

Varshney RK, Graner A and Sorrells ME (2005). Genic microsatellite markers in plants: features and applications. Trends Biotechnol. 23: 48-55.http://dx.doi.org/10.1016/j.tibtech.2004.11.005

Wang XF, Zheng HY, Zheng WH, Ao CQ, et al. (2011). RAPD-based genetic diversities and correlation with morphological traits in Camellia (Theaceae) cultivars in China. Genet. Mol. Res. 10: 849-859. http://dx.doi.org/10.4238/vol10-2gmr1207

Yan Y, Zhong LX, Zhang NX, Zhang XM, et al. (2012). Grafting affinity of different rootstock and scion combinations in grapefruit. Nonwood Forest Res. 30: 103-107.

Chung MY, Epperson BK and Chung MG (2003). Genetic structure of age classes in Camellia japonica (Theaceae). Evolution 57: 62-73.http://dx.doi.org/10.1111/j.0014-3820.2003.tb00216.x

Zaloglu S, Kafkas S, Dogan Y and Guney M (2015). Development and characterization of SSR markers from pistachio (Pistacia vera L.) and their transferability to eight Pistacia species. Sci. Hortic. (Amsterdam) 189: 94-103. http:// dx.doi.org/10.1016/j.scienta.2015.04.006

Zhan Y (1999). Animal feed compositions and uses of triterpenoid saponin obtained from Camellia L. plants. United States Patent 6007822.

Zhang LW, Cai RR, Yuan MT, Tao AF, et al. (2015). Genetic diversity and DNA fingerprinting in jute (Corchorus spp.) based on SSR markers. Crop J. 3: 416-422. http://dx.doi.org/10.1016/j.cj.2015.05.005

Genetics and Molecular Research 16 (1): gmr16019526 